\title{
Epigallocatechin Gallate Menghambat Resistensi Insulin pada Tikus dengan Diet Tinggi Lemak
}

\section{Inhibitory Effect of Epigallocatechin Gallate on Insulin Resistance in Rat with High Fat Diet}

\author{
Herin Mawarti ${ }^{1}$, Retty Ratnawati $i^{2}$,Diana Lyrawati ${ }^{3}$ \\ ${ }^{1}$ Fakultas Ilmu Kesehatan Universitas Pesantren Tinggi Darul 'Ulum Jombang \\ ${ }^{2}$ Laboratorium Ilmu Faal Fakultas Kedokteran Universitas Brawijaya Malang \\ ${ }^{3}$ Laboratorium Farmasi Klinis Fakultas Kedokteran Universitas Brawijaya Malang/Rumah Sakit Umum Dr. Saiful Anwar \\ Malang
}

\begin{abstract}
ABSTRAK
Konsumsi Epigallocatechin Gallate (EGCG) teh hijau dilaporkan banyak bermanfaat pada upaya peningkatan kesehatan, seperti pembakaran lemak, mencegah obesitas dan sensitifitas insulin. Sehingga teh hijau (Camelia sinensis) dari klon GMB4 dapat dikembangkan sebagai agen terapeutik potensial untuk obesitas dan resistensi insulin. Penelitian ini bertujuan untuk membuktikan Epigallocatechin Gallate (EGCG) teh hijau dapat menghambat peningkatan kadar SREBP-1 jaringan adiposa dan resistensi insulin pada tikus galur wistar jantan yang diberi diet tinggi lemak. Penelitian ini dilakukan secara invivo dengan pemeliharaan hewan coba selama 8 minggu yang dibagi dalam lima kelompok perlakuan: (1) kelompok kontrol (-) dengan pemberian diet pakan standart, (2) kelompok kontrol (+) dengan pemberian diet tinggi lemak, (3)Pemberian diet tinggi lemak+EGCG 1mg/kgBB, (4) Pemberian diet tinggi lemak+EGCG $2 \mathrm{mg} / \mathrm{kgBB}$, (5) Pemberian diet tinggi lemak+EGCG $8 \mathrm{mg} / \mathrm{kgBB}$. Pakan tikus diberikan secara oral, sedangkan EGCG per sonde $1 \mathrm{x} / \mathrm{hr}$. Metode yang digunakan dalam penelitian ini adalah ELISA untuk kadar insulin dan SREBP-1 jaringan adiposa dan spektrofotometri untuk glukosa darah puasa. EGCG menurunkan lemak viseral, kadar glukosa, kadar SREBP-1 dan resistensi insulin (HOMA-IR) $(p<0,05)$. Penurunan kadar SREBP-1 secara signifikan sebesar 29,85\%( $<<0,05)$ pada dosis 8 $\mathrm{mg} / \mathrm{kgBB}$, sedangkan HOMA-IR menurun secara signifikan sebesar $33,89 \%(p<0,05)$ pada dosis $8 \mathrm{mg} / \mathrm{kgBB}$. Terdapat hubungan antara kadar SREBP-1 dengan resistensi insulin (HOMA-IR) $(p<0,05)$. Hasil penelitian ini membuktikan bahwa EGCG mampu menghambat resistensi insulin yang mungkin melalui penurunan adipo/lipogenesis SREBP-1 jaringan adiposa, dengan bukti adanya penurunan kadar SREBP-1 jaringan adiposa dan lemak viseral.
\end{abstract}

Kata Kunci: EGCG, glukosa, HOMA-IR, insulin, SREBP-1 jaringan adipose, tikus diet tinggi lemak

\begin{abstract}
Consumption of epigallocatechin gallate (EGCG) of green tea were reported to have much benefit in improving health, such as increased fat oxidation, prevent obesity and improve insulin sensitivity. EGCG of green tea (Camelia sinensis) from GMB4 clone may serve as a potential therapeutic agent for obesity and insulin resistance. This study investigated the effect isolat Epigallocatechin Gallate (EGCG) from green tea inhibit increasing adipose tissue sterol regulatory element-binding protein 1(SREBP-1) and insulin resistance in male rats with high fat diet. Wistar male rats were fed a diet high in fat for 2 months from 6-8 weeks of age and determination of the object of research with completely randomized design with five treatments, namely (1) rats with standard feed diet (2) rats with a diet high in fat, (3) rats with high-fat diet + EGCG $1 \mathrm{mg} / \mathrm{kgBW}$, (4) rats with high-fat diet + EGCG $2 \mathrm{mg} / \mathrm{kgBW}$, (5) rats with high-fat diet + EGCG $8 \mathrm{mg} / \mathrm{kgBW}$. Feeding rats administered orally, whereas EGCG per sonde 1x/day. Plasma Insulin and adipose tissue SREBP-1 was measured by ELISA and blood glucose by spektrophotometry. EGCG treatment decreased visceral fat, blood glucose, insulin, and HOMA-IR $(p<0.05)$ compared with high-fat diet without EGCG treatment. SREBP-1 levels decreased significantly by $29,85 \%(p<0,05)$ at doses of $8 \mathrm{mg} / \mathrm{kgBW}$ and HOMA-IR decreased significantly by 33,89\% $(p<0,05)$ at doses of $8 \mathrm{mg} / \mathrm{kgBW}$. The Results suggested that EGCG effectively inhibits insulin resistance. These effects may be mediated by decreased adipose tissue adipo/lipogenesis involving SREBP-1, decreased visceral fat.
\end{abstract}

Keywords : Adipose tissue SREBP-1, EGCG, glucose, HOMA-IR, male rats with high fat diet, insulin

Jurnal Kedokteran Brawijaya, Vol. 27, No. 1, Februari 2012; Korespondensi: Herin Mawarti. Fakultas Ilmu Kesehatan Universitas Pesantren Tinggi Darul 'Ulum Jombang, Jl. PP Darul 'Ulum Peterongan Jombang 61481 Tel. (0321) 860156 Email: herma_du@yahoo.com 


\section{PENDAHULUAN}

Obesitas saat ini menjadi masalah global baik di negara maju ataupun berkembang seperti di Indonesia. Obesitas menjadi faktor resiko utama terhadap penyakit kardiovaskuler, hipertensi, dislipidemia dan diabetes mellitus. Diseluruh dunia dari 1 milyar orang dewasa adalah overweight dan lebih dari 300 juta obese (1). Prevalensi nasional obesitas umum pada penduduk berusia kurang lebih 15 tahun adalah 19,1\%, dengan prevalensi pada laki-laki 13,9\%, sedangkan pada perempuan $23,8 \%(2)$.

Diet tinggi lemak dapat menyebabkan peningkatan ukuran sel lemak (hipertropi) dan peningkatan jumlah sel (hiperplasia) (3). Pertambahan ukuran sel melalui lipogenesis mengawali pertambahan jumlah sel (adipogenesis) dari pre adiposit melalui proliferasi dan diferensiasi menjadi sel adiposit yang matang (4), dan dalam regulasinya diatur oleh faktor transkripsi Sterol regulalatory element binding protein (SREBP)1 (5). Dalam kondisi makan berlebih yang kaya akan gula, karbohidrat dan saturated fatty acid (SFA), SREBP-1 akan meningkat untuk sintesis lemak seperti asam lemak, trigliserida, phospolipid (6).

Sterol regulalatory element binding protein (SREBP)-1 memegang peran penting untuk mengatur gen adiposit, antara lain sintesis asam lemak (7), lipoprotein lipase (LPL) dan metabolisme asam lemak $(8,9)$. Ekspresi SREBP-1c pada tikus dipengaruhi oleh status nutrisi dan insulin. Seperti puasa menurunkan mRNA SREBP-1c dan sintesis 70\%-90\% asam lemak pada adiposa dan liver, nutrisi akan meningkatkan mRNA SREBP-1c (10). Di adiposit insulin meningkatkan lipogenesis dengan menstimulasi pengambilan glukosa dan lipoprotein-derivat fatty acid melalui induksi ADD-1/SREBP-1c (11).

Diet tinggi lemak menyebabkan hiperinsulinemia yang akan menyebabkan peningkatan kerja SREBP-1 adiposit sehingga terjadi hipertropi di adiposit. Kemudian terbentuk adiposit baru oleh insulin growth factor1(IGF1). Produksi dari adiposit baru meningkatkan pembentukan adiposit yang baru lagi sehingga terjadi hiperplasi adiposit, dan FFA(Free faty acids) semakin meningkat (12). Peningkatan FFA plasma mempengaruhi kerja insulin, menurunkan pengambilan glukosa, glikolisis, sintesis glikogen (13).

Diet tinggi lemak secara kronik kurang lebih selama 8 minggu menyebabkan resistensi insulin akibat dari penumpukan lemak viseral, dimana peningkatan masa lemak viseral menyebabkan peningkatan FFA (Free faty acids) menuju liver, meningkatnya sirkulasi trigliserida dan kecepatan produksi glukosa hepatic (14). Menurut Blaak (2007), obesitas yang menimbulkan resistensi insulin adalah obesitas abdominal dan terdapat hubungan langsung antara diet lemak dengan sensitifitas insulin, tidak tergantung pada berat badan tetapi dari kualitas diet lemak yaitu diet dengan tinggi asam lemak terutama adalah saturated fatty acid (SFA) (15).

Peningkatan hipertropi dan hiperplasia pada obesitas menyebabkan peningkatan sekresi sitokin (16). Makin banyak jaringan adiposa maka semakin banyak asam lemak bebas yang dilepas. Sel adiposa menghasilkan sejumlah besar sitokin pro-inflamasi seperti tumor necrosis factor-alpha (TNF- $\alpha$ ) dan interleukin -1 dan 6, leptin, adiponektin. Banyak studi eksperimental mengganggu aksi normal dari insulin dan mungkin menjadi faktor penyebab utama dari resistensi insulin pada sel lemak dan otot (17).

Produk natural dengan rendah toksisitas seperti poliphenol green tea yang berisi epigallocatechin gallate (EGCG) diperlukan sebagai anti obesitas dimana mempunyai kemampuan mensupresi adipo/lipogenesis dan pengambilan asam lemak ke dalam jaringan adiposa, dengan peningkatan sistesis dan oksidasi lemak oleh hepar, tanpa menyebabkan akumulasi lemak pada hepar $(18,19)$.

Pemberian EGCG dapat mengurangi lemak dan berat badan, meningkatkan penggunaan energi dan metabolisme, menurunkan absorbsi lemak dan peningkatan oksidasi lemak, meningkatkan kerja insulin, menurunkan akumulasi trigliserida melalui penghambatan adipogenesis dan mempengaruhi kerja gen sintesis asam lemak yaitu SREBP-1, sehingga EGCG bisa digunakan sebagai terapi pencegahan obesitas dan resistensi insulin. Akan tetapi bagaimana mekanismenya pengaruh EGCG terhadap resistensi insulin masih belum banyak dipelajari. Pada penelitian sebelumnya dijelaskan EGCG berpengaruh terhadap resistensi insulin melalui penurunan absorbsi lemak, dan penurunan inflamasi (18, 20-24).

Ratnawati et al telah melakukan isolasi dan purifikasi golongan senyawa katekin dan EGCG pada pucuk daun ketiga camellia sinensis varitas assamica $(p+3)$ dari klon (GMB 4) yang diperoleh dari Lembaga penelitian teh dan kina (PPTK) Gambung, Ciwidey Bandung, Jawa Barat. Dari $100 \mathrm{gr}$ teh hijau tersebut terdapat $14 \%-16 \%$ isolat golongan senyawa katekin. Dan sudah dilaksanakan studi secara in vitro, untuk itu perlu dilaksanakan secara in vivo untuk mengetahui potensi yang dimiliki oleh EGCG sehingga bisa dimanfaatkan sebagai alternatif pencegahan obesitas beserta resiko komplikasinya. Berdasarkan uraian diatas maka penulis ingin membuktikan bahwa Epigallocatechin gallate (EGCG) teh hijau menghambat peningkatan kadar SREBP-1 dan resistensi insulin pada tikus galur wistar jantan yang diberi diet tinggi lemak (25).

\section{METODE}

\section{Desain Penelitian}

Penelitian ini termasuk eksperimental laboratorik dengan desain penelitian menggunakan control group post test design. Penentuan objek penelitian dengan rancangan acak lengkap dengan lima perlakuan, yaitu (1) tikus dengan diet pakan standart, (2) tikus dengan diet tinggi lemak, (3) tikus dengan diet tinggi lemak+EGCG $1 \mathrm{mg} / \mathrm{kgBB}$, (4) tikus dengan diet tinggi lemak+EGCG $2 \mathrm{mg} / \mathrm{kgBB}$, (5) tikus dengan diet tinggi lemak+EGCG $8 \mathrm{mg} / \mathrm{kgBB}$. Perlakuan dilaksanakan selama 60 hari. Kelayakan etik penelitian dari Fakultas Kedokteran Universitas Brawijaya Malang dengan No.108/EC/KEPK-S2-JK/05/2011 (25).

EGCG didapatkan dari isolasi dan purifikasi teh kon (GMB4) oleh Ratnawati et al, yang diperoleh dari PPTK Gambung, Ciwedey, Bandung. Sampel yang digunakan adalah tikus percobaan berjumlah 25 ekor sesuai dengan kriteria inklusi dan eksklusi sebagai berikut, kriteria inklusi: Tikus jenis Rattus norvegicus strain wistar, jenis kelamin jantan, umur 6-8 minggu, berat badan antara 150 gram s.d. 200 gram, warna bulu putih tikus aktif dan kriteria eksklusi: tikus yang tidak mau makan dan tikus yang mengalami 
penurunan keadaan fisik atau mati.

Waktu dan tempat penelitian di Laboratorium IImu Faal Fakultas Kedokteran Universitas Brawijaya

\section{Pemeriksaan Kadar Insulin Plasma dengan Metode ELISA}

Kadar insulin plasma diukur mengunakan metode ELISA dari Boehringermannheim kit. Darah yang sudah diambil diberi antikoagulan/EDTA lalu diputar menggunakan sentrifugator dengan kecepatan $3000 \mathrm{rpm}$ selama 7 menit. Pengukuran insulin mengunakan kit. Prosedur pengukuran dengan ELISA kit yaitu tabung diisi plasma dari tiap-tiap kelompok perlakuan, lalu diberi reagen standart dengan pipet $25 \mu \mathrm{L}$. dan ditambah enzim conjugated dengan pipet $100 \mu \mathrm{L}$. Tabung diinkubasi selama 30 menit dengan suhu $25^{\circ} \mathrm{C}$ setelah itu dicuci dengan washing buffer. Kemudian tambahkan $100 \mu \mathrm{L}$ solution A (buffer solution containing $\mathrm{H}_{2} \mathrm{O}_{2}$ ), kemudian solution B (tetramethylbenzidine) lalu inkubasi selama 15 menit. Setelah itu tambahkan $50 \mu \mathrm{L}$ stop solution ( $2 \mathrm{~N} \mathrm{HCL}$ ) dan baca pada $\lambda 450$

\section{Pemeriksaan Kadar SREBP-1 dengan Metode ELISA}

Preparasi jaringan adiposa kemudian dicuci, ditimbang $100 \mathrm{mg}$ kemudian digerus dengan mortart, ditambah (ripalisis buffer $+\mathrm{PIC}+\mathrm{PMS} \pm 1 \mathrm{ml}$ ), homogenase jaringan, inkubasi 30 menit on ice, sentrifuse $12.000 \mathrm{rpm}$ dalam 20 menit, $4^{\circ} \mathrm{C}$. Ambil supernatan dan simpan dalam T-20 $20^{\circ}$. Prosedur pengukuran SREBP-1 mengikuti panduan manual kit ELISA dari Cusabio Biotech co., Ltd., China. Sebanyak $100 \mu \mathrm{L}$ larutan sampel suspensi protein dari sampel, dan blanko dimasukkan ke dalam well lalu diinkubasi selama 2 jam dalam suhu $37^{\circ} \mathrm{C}$ selanjutnya larutan tersebut dibuang lalu ditambahkan dengan $100 \mu \mathrm{L}$ biotin antibody working solution lalu diinkubasi selama 1 jam dalam suhu $37^{\circ} \mathrm{C}$ kemudian dicuci dengan wash buffer $200 \mu \mathrm{L}$ sebanyak 3 kali. Selanjutnya ditambahkan dengan $100 \mu \mathrm{L}$ HRP avidin lalu diikubasi selama 1 jam dalam suhu $37^{\circ} \mathrm{C}$ lalu dicuci kembali dengan wash buffer $200 \mu \mathrm{L}$ sebanyak 3 kali kemudian ditambahkan $90 \mu \mathrm{L}$ TMB subtrat lalu dinkubasi 10 hingga 30 menit dalam suhu $37^{\circ} \mathrm{C}$ lalu dakhiri dengan pemberian $50 \mu \mathrm{L}$ stop solution lalu dibaca pada $\lambda 450 \mathrm{~nm}$ dengan ELISA reader.

\section{Pemeriksaan Kadar Glukosa Puasa}

Pengambilan darah dari jantung, $\pm 3 \mathrm{ml}$, lalu diputar menggunakan sentrifugator dengan kecepatan $3000 \mathrm{rpm}$ 10 menit $(2 \mathrm{x})$, diambil serumnya. Pengukuran glukosa dengan specific colorimetric assays (Horiba $A B X$ Diagnostics, Montpellier, France) diukur dengan sistem analisis otomatis (COBAS MIRA, Roche, Basel, Switzerland). Untuk mengukur glukosa serum menggunakan HK-CP kit (ABX Pentra, Montpellier, France).

\section{Pengukuran Resistensi Insulin}

Resistensi insulin dihitung dengan HOMA-IR (homeostasis model assessment of insulin resistance). Metode ini digunakan dalam penghitungan resistensi insulin pada manusia dan binatang coba (5). Dengan menggunakan rumus US formula yaitu :

gula darah puasa $(\mathrm{mg} / \mathrm{dl})$ dikalikan Insulin puasa $(\mu \mathrm{U} / \mathrm{ml})$ dibagi dengan 405.

\section{HASIL}

Penelitian ini merupakan penelitian in vivo dengan menggunakan hewan coba dari tikus Rattus norvegicus Wistar yang diberi diet tinggi lemak selama 2 bulan dilakukan berdasarkan pertimbangan penelitian yang dilakukan oleh Wilde menunjukkan bahwa diet tinggi lemak yang diberikan selama 8 minggu dapat menginduksi obesitas dan resistensi insulin, meningkatnya sirkulasi trigliserida dan kecepatan produksi glukosa hepatic (26).

\section{Lemak Viceral}

Efek EGCG terhadap berat lemak viseral seperti terlihat pada Tabel 1 diketahui bahwa berat lemak viseral yang lebih tinggi terdapat pada kelopok perlakuan kontrol positif diet tinggi lemak $(17,74 \pm 0,666)$ dan terendah pada kontrol negatif $(8,25 \pm 0,666)$. Dengan pemberian EGCG $8 \mathrm{mg} / \mathrm{kgBB}$ mampu menurunkan berat lemak viseral sebesar 48,99\% jika dibandingkan dengan kelompok kontrol (+) yang mendekati dengan kontrol (-).

Dari Tabel 1 hasil uji stastitik One Way ANOVA ( $\alpha \quad 0,05)$ diketahui ada pengaruh signifikan pada pemberian EGCG terhadap berat lemak viseral $(p=0,00)$. Hasil pengujian berganda dengan uji Tukey terdapat perbedaan bermakna yang signifikan berat lemak viseral pada kelompok kontrol $(+)$ dengan kelompok kontrol $(-)(p=0,00), E G C G 1 \mathrm{mg} / \mathrm{kgBB}$ $(p=0,00)$, kelompok EGCG $2 \mathrm{mg} / \mathrm{kgBB}(p=0,00)$ dan

Tabel 1. Efek EGCG pada lemak viseral, SREBP-1, insulin, glukosa darah dan HOMA-IR pada tikus dengan diet tinggi lemak.

\begin{tabular}{|c|c|c|c|c|c|}
\hline Variabel & Kontrol (+) & Kontrol(-) & EGCG 1mg/kgBB & EGCG $2 \mathrm{mg} / \mathrm{kgBB}$ & EGCG $8 \mathrm{mg} / \mathrm{kgBB}$ \\
\hline Visceral Adipose (gr) & $8,25 \pm 0,66 * a)$ & $\left.17,74 \pm 0,66{ }^{*} \mathrm{c}\right)$ & $12,45 \pm 1,36 * b)$ & $11,62 \pm 2,03 * b)$ & $9,05 \pm 0,66 * a)$ \\
\hline SREBP-1(ng/ml) & $36,76 \pm 5,08 * a)$ & $68 \pm 17,66 * b)$ & $\left.64,31 \pm 11,11^{*} a\right)$ & $\left.54,94 \pm 11,76^{*} a b\right)$ & $47,96 \pm 13,05 * c)$ \\
\hline Insulin( $\mu \mathrm{u} / \mathrm{ml})$ & $4,55 \pm 0,64 * a)$ & $\left.4,80 \pm 0,45^{*} a\right)$ & $4,89 \pm 0,62 * a)$ & $4,80 \pm 0,40 * a)$ & $\left.4,03 \pm 0,31^{*} a\right)$ \\
\hline Blood Glucose (mg/dl) & $87,40 \pm 2,41^{*}$ a) & $\left.201,8 \pm 8,53^{*} c\right)$ & $192,40 \pm 9,34 * c)$ & $\left.186,20 \pm 8,43^{*} c\right)$ & $158,80 \pm 16,02 * b)$ \\
\hline HOMA-IR & $\left.0,98 \pm 0,15^{*} a\right)$ & $\left.2,39 \pm 0,26^{*} c\right)$ & $2,32 \pm 0,32 * c)$ & $2,21 \pm 0,29 * c)$ & $\left.1,58 \pm 0,17^{*} b\right)$ \\
\hline
\end{tabular}

Keterangan:

* Data di sajikan dalam mean $\pm \mathrm{SD}, \mathrm{n}=5$. Statistik dengan One Way ANOVA

* Subset yang berbeda menunjukkan perbedaan yang signifikan $\mathrm{P}<0,05$

* Subset yang sama menunjukkan tidak ada perbedaan yang nyata $\mathrm{P}>0,05$ 
kelompok EGCG 8mg/kgBB $(p=0,00)$. Dari hasil tersebut dapat disimpulkan bahwa pemberian EGCG memberikan perbedaan yang signifikan terhadap berat lemak viseral pada masing-masing kelompok perlakuan.

\section{Kadar SREBP-1 Jaringan Adiposa}

Untuk mengetahui efek EGCG (Epigallocatechin gallate) teh hijau dapat mempengaruhi SREBP-1 jaringan adiposa pada Rattus norvegicus strain Wistar jantan yang diberi diet tinggi lemak, maka dilakukan pengukuran kadar dari protein tersebut. Kadar SREBP-1 yang diukur dengan metode ELISA. Dari berbagai kelompok perlakuan menunjukkan kadar yang berbeda-beda dan berbeda secara signifikan dengan kontrol (-). Kadar protein SREBP1 yang lebih tinggi terdapat pada kelompok perlakuan kontrol $(+)$ diet tinggi lemak $(68 \pm 17,66)$ dan terendah pada kontrol (-) $(36,76 \pm 5,08)$. Dengan pemberian EGCG terdapat penurunan kadar SREBP-1 yang semakin rendah seiring dengan penambahan dosis, dan pemberian dosis yang efektif terjadi pada dosis EGCG $8 \mathrm{mg} / \mathrm{kgBB}$ $(47,96 \pm 13,05)$. Seperti terlihat pada Tabel 1 .

Hasil uji stastitik One Way ANOVA $(\alpha \quad 0,05)$ diketahui ada pengaruh signifikan pada pemberian EGCG terhadap kadar SREBP-1 $(p=0,005)$. Hasil pengujian berganda dengan uji Tukey terdapat perbedaan yang signifikan kadar SREBP-1 yang antara kelompok kontrol (+) dengan kelompok kontrol $(-)(p=0,001)$ dan kelompok EGCG $8 \mathrm{mg} / \mathrm{kgBB} \quad(p=0,019)$. Dari hasil tersebut dapat disimpulkan bahwa pemberian EGCG memberikan perbedaan yang signifikan terhadap kadar SREBP-1 pada masing-masing kelompok perlakuan dan pada dosis EGCG $8 \mathrm{mg} / \mathrm{kgBB}$ mampu menurunkan kadar SREBP-1 sebesar $29,85 \%$ dibandingkan dengan kelompok kontrol (+) diet tinggi lemak.

\section{Kadar Insulin Plasma Puasa}

Hasil pengukuran kadar insulin plasma darah pada masing-masing kelompok perlakuan dengan EGCG digambarkan pada Tabel 1. Kadar insulin plasma puasa yang lebih tinggi terdapat pada kelompok perlakuan EGCG $1 \mathrm{mg} / \mathrm{kgBB}(4,89 \pm 0,62)$. Dan terendah pada kelompok perlakuan dengan dosis EGCG $8 \mathrm{mg} / \mathrm{kgBB}$ $(4,03 \pm 0,31)$. Tidak ada perbedaan rata-rata kadar insulin plasma puasa pada masing-masing kelompok perlakuan.

Hasil uji stastitik One Way ANOVA $(\alpha \quad 0,05)$ diketahui tidak ada pengaruh signifikan pada pemberian EGCG terhadap kadar insulin plasma puasa $(p=0,08)$.

\section{Kadar Glukosa Darah Puasa}

Hasil pengukuran kadar glukosa darah puasa pada masingmasing kelompok perlakuan dengan EGCG terlihat pada Tabel 1. Kadar glukosa darah puasa yang lebih tinggi terdapat pada kelompok perlakuan kontrol (+) diet tinggi lemak $(201,8 \pm 8,53)$ dan terendah pada kontrol (-) $(87,40$ $\pm 2,41)$. Hasil uji stastitik $(\alpha 0,05)$ diketahui ada pengaruh signifikan pada pemberian EGCG terhadap kadar glukosa darah puasa $(p=0,00)$. Terdapat perbedaan yang signifikan kadar glukosa antara kelompok kontrol $(+)$ dengan kelompok EGCG $2 \mathrm{mg} / \mathrm{kgBB}(p=0,016)$ dan EGCG 8 $\mathrm{mg} / \mathrm{kgBB}(\mathrm{p}=0,08)$.

HOMA-IR (Homeostasis model assessment of insulin resistance)

Untuk mengetahui efek EGCG (Epigallocatechin gallate) teh hijau dapat menghambat resistensi insulin pada
Rattus norvegicus strain Wistar jantan yang diberi diet tinggi lemak, maka dilakukan pengukuran resistensi insulin dengan HOMA-IR. Hasil pengukuran HOMA-IR pada masing-masing kelompok perlakuan dengan EGCG terlihat pada Tbel 1. HOMA-IR yang lebih tinggi terdapat pada kelompok perlakuan kontrol (+) diet tinggi lemak $(2,39 \pm 0,26)$ dan terendah pada kontrol $(-)(0,98 \pm 0,15)$. Dengan pemberian EGCG HOMA-IR semakin menurun seiring dengan penambahan dosis dan dosis efektif yang mampu menurunkan adalah EGCG $8 \mathrm{mg} / \mathrm{kgBB}(1,58 \pm 0,17)$ $(p=0,00)$. Hasil pengujian berganda dengan uji Tukey terdapat perbedaan yang signifikan pengukuran HOMA-IR antara kelompok kontrol positif dengan kelompok kontrol $(-)(p=0,00)$ dan kelompok EGCG $8 \mathrm{mg} / \mathrm{kgBB}(\mathrm{p}=0,00)$.

Hubungan antara kadar SREBP-1 dengan Resistensi Insulin (HOMA-IR)

Berdasarkan analisis uji statistik dengan Spearman corelation didapatkan data $p=0,001$ dan $r=0,603$. Yang berarti terdapat hubungan antara SREBP-1 dengan resistensi insulin (HOMA-IR) mempunyai korelasi yang kuat dan arah positif. Semakin tinggi Kadar SREBP-1 maka resistensi insulin semakin rendah.

\section{DISKUSI}

Pada penelitian ini hewan coba diberi diet tinggi lemak dengan tujuan untuk menginduksi terjadinya obesitas dan resistensi insulin sebagaimana telah dilakukan pada penelitian sebelumnya, dimana bukti epidemiologi menyatakan bahwa kejadian resistensi insulin dan obesitas berhubungan dengan diet tinggi lemak (27). Hewan coba diberi diet tinggi lemak selama 8 minggu, dengan diet lemak selama 8 minggu sudah dinyatakan kronik akan menyebabkan penumpukan lemak viseral, dimana peningkatan masa lemak visceral menyebabkan peningkatan FFA (Free faty acids) menuju liver, meningkatnya sirkulasi trigliserida dan kecepatan produksi glukosa hepatic (14). Peningkatan FFA plasma mempengaruhi kerja insulin, menurunkan pengambilan glukosa, glikolisis, sintesis glikogen (28). Stimulasi resistensi insulin melalui pemberian diet tinggi lemak diduga melalui mekanisme aktifasi jalur ROS dan PKC. Supresi ekspresi glucose transporter 4 (GLUT 4), yaitu adanya aktifasi ROS karena adanya peningkatan asam lemak bebas (FFA). Diet tinggi lemak menyebabkan hiperinsulinemia yang akan menyebabkan peningkatan kerja SREBP-1 adiposit sehingga terjadi hipertropi di adiposit, kemudian terbentuk adiposit baru oleh insulin growth factor-1(IGF-1) dan produksi dari adiposit baru meningkatkan pembentukan adiposit yang baru lagi sehingga terjadi hiperplasi adiposa, dan FFA semakin meningkat (12). Hal ini menunjukkan SREBP-1 memegang peranan disini karena berperan sebagai lipogenik, adipogenik dan sintesa asam lemak.

Penelitian dilakukan pada tikus Rattus norvegicus strain Wistar jantan, dengan pertimbangan selain untuk homogenisasi sampel alasan lain jenis kelamin itu mempengaruhi berat badan. Dimana dibandingkan lakilaki, perempuan premenopause lebih sensitif terhadap insulin, hal ini dihubungkan dengan jumlah lemak viseral yang lebih kecil (meskipun secara keseluruhan perempuan mempunyai $30 \%$ lebih banyak lemak). Kemungkinan sensitifitas insulin yang lebih baik itu berhubungan dengan peran estrogen. Estrogen dapat diproduksi di jaringan adiposa dari aromatisasi androgen sirkulasi melalui oleh 
kerja aromatase dan ekspresi ini lebih tinggi di lemak sub kutan dari pada viseral (29). Bukti pada model dengan kekurangan estrogen menunjukkan signaling estrogen berkontribusi pada pengaturan berat badan dan tidak adanya estrogen berhubungan dengan obesitas, resistensi insulin, intoleransi glukosa, efek jangka panjang terjadi sindroma metabolik (30). Jaringan lemak viseral relatif kurang estrogen dibandingkan dengan lemak subkutan. Jumlah di jaringan adipose lebih banyak pada laki laki dan wanita menopaus. Teh hijau dapat menginduksi peningkatan ekspresi aromatase dan konsentrasi $17 \mathrm{~b}$-estradiol di sel lemak sehingga dengan pemberian teh hijau juga dapat menurunkan berat badan melalui peningkatan estrogen (29).

Bose et al, membuktikan bahwa pemberian EGCG selama 16 minggu menurunkan jumlah lemak tubuh dan viseral (mesenteric, epididimal dan retroperitoneal), penurunan simpanan lemak ini karena penghambatan absorbsi lemak atau peningkatan oksidasi lemak, dan pada penelitian ini didapatkan peningkatan fekal lipid. Penurunan lemak viseral lebih efektif menurunkan resiko sindroma metabolic dibandingkan dengan lemak subkutan. Mekanisme EGCG menurunkan glukosa, insulin dan resistensi insulin melalui ambilan glukosa ke otot dan meningkatkan glukoneogenesis, menurunkan ekspresi enzim glukoneogenesis dan G6PD di liver (14,31,32).

Pada penelitian ini terjadi penurunan kadar SREBP-1 secara signifikan pada dosis EGCG $8 \mathrm{mg} / \mathrm{kgBB}$, dimana kadar SREBP-1 dapat turun sebesar 29,85\% dibanding kontrol (+) yang tanpa pemberian EGCG. Walaupun penurunannya tidak seperti pada kelompok kontrol(-) yang tidak diberi EGCG dan dietnya standar. Dengan demikian dapat diartikan bahwa dengan diet tinggi lemak ketika diberi EGCG, Kadar SREBP-1 bisa terjadi penurunan mulai dengan dosis EGCG $8 \mathrm{mg} / \mathrm{kgBB}$. Pada kelompok kontrol positif tikus dengan diet tinggi lemak ditemukan kadar SREBP-1 paling tinggi, padahal kadar insulin antara yang kontrol (-) dan kontrol (+) tidak ada bedanya, sehingga peningkatan kadar SREBP-1 disini tidak dipengaruhi oleh insulin tetapi faktor yang lain. Hal ini bertentangan dengan penelitian Unger \& Orci, dengan diet tinggi lemak menyebabkan hiperinsulinemia yang akan menyebabkan peningkatan kerja SREBP-1 adiposit sehingga terjadi hipertropi dan hiperplasi sel adiposit (12).

Sterol regulalatory element binding protein (SREBP)1 memegang peran penting dalam kerja insulin untuk mengatur ekspresi gen adiposit. Menurut Desvergne et al, faktor transkripsi yang meregulasi gen metabolisme asam lemak antara lain SREBPs, CEBPs dan anggota famili nuclear reseptor. Dalam proses adipogenesis sel adiposa mengalami proliferasi dan differensiasi selanjutnya mempunyai fungsi yang spesifik yaitu penyimpanan lemak dan memproduksi hormon adiposa (adipokins). Selain itu juga Lipogenesis menghasilkan akumulasi lipid seluler melalui uptake lipogenik dari diet, sintesis asam lemak endogen dan penimbunan asam lemak seperti trigliserida $(5,9)$.

Sementara itu Flavonoid termasuk didalamnya catekins mempengaruhi lipolisis dan adipogenesis didalam sel adiposa, menurunkan ekspresi mRNA SREBP-1 yang merupakan kunci faktor transkripsi adipogenesis. Mekanisme penghambatan katekin yakni EGCG terhadap diferensiasi sel preadiposit diduga terkait dengan jalur
MAPK (Mitogen-Activated Protein Kinase), khususnya extracellular signal regulated kinases (ERKs) yang distimulasi oleh sinyal-sinyal faktor pertumbuhan. Menurut Chien et al flavonoid yakni catechin, quercetin dan kaemferol terbukti mampu menghambat adipogenesis sel preadiposit 3T3-L1 melalui penekanan ekspresi faktor transkripsi yakni SREBP-1, C/EBP $\alpha$ dan PPARY. Sementara itu menurut Shrestha et al. 36, dengan diet ekstrak teh hijau dapat menurunkan ekspresi mRNA SREBP-1 hepatik, dimana mekanisme penurunannnya dimediasi oleh penghambatan lipogenesis (33-35).

Pada penelitian ini penurunan HOMA-IR secara signifikan sampai dengan dosis EGCG $8 \mathrm{mg} / \mathrm{kgBB}$ yaitu sebesar $21,3 \%$ karena pada dosis sebelumnya yaitu 1 dan 2 $\mathrm{mg} / \mathrm{kgBB}$ tidak ada perbedaan yang bermakna. Dengan demikian ketika konsumsi makanan yang mengandung tinggi lemak dengan pemberian EGCG $8 \mathrm{mg} / \mathrm{kgBB}$ baru dapat menurunkan HOMA-IR (homeostasis model assessment of insulin resistance) akan tetapi belum bisa mengembalikan ke keadaan dengan diet tanpa tinggi lemak (kontrol negatif). Dengan diet tinggi lemak selama selama 8 minggu (kronik) akan menyebabkan penumpukan lemak viseral, dimana peningkatan masa lemak viseral menyebabkan peningkatan FFA (Free fatty acids) menuju liver, meningkatnya sirkulasi trigliserida dan kecepatan produksi glukosa hepatik (14). Dari berbagai penelitian dijelaskan bahwa penumpukan lemak viseral merupakan penyebab timbulnya resistensi insulin dibandingkan adiposa subkutan (36). Seperti yang terlihat pada penelitian ini dimana berat lemak viseral menurun pada pemberian EGCG dengan dosis $8 \mathrm{mg} / \mathrm{Kg} / \mathrm{BB}$. Penurunan lemak viseral ini seiring dengan penurunkan HOMA-IR, sehingga bisa disimpulkan bahwa peningkatan lemak viseral mampu mampu meningkatkan HOMA-IR.

Mekanisme tinggi lemak meningkatkan resistensi insulin karena dengan diet tinggi lemak dapat menyebabkan obesitas yang akan meningkatkan kerja SREBP-1, yaitu faktor transkripsi adipo/lipogenik dan sintesis trigliserida. Meskipun kelebihan lemak dalam tubuh disimpan didalam jaringan adiposa (trigliserida), trigliserida akan mengalami hidrolisis oleh enzim lipoprotein lipase menjadi asam lemak bebas (FFA) (37). FFA yang dilepaskan masuk ke jaringan nonadiposa, meningkatkan TG pada jaringan nonadiposa dan menyebabkan kerusakan oksidatif (13). Kelebihan asam lemak disirkulasi juga juga disimpan di liver, hati, pankreas dan otot skeletal. Dijaringan ini akumulasi lemak intraselular berhubungan dengan penurunan sensitifitas insulin, dan bagaimana mekanismenya masih belum jelas diduga karena intermediet asam lemak seperti diasilgliserol, fatty acylcoenzyme-A dan ceramides, dapat menghambat signaling insulin, selain oleh karena reactive oksigen spesies, asam lemak bersama dengan oksidasi stres juga dapat menimbulkan kerusakan oksidasi karena lemak, mengganggu fungsi mitokondrial dan penumpukan lemak muscular. Peningkatan FFA menggangu insulin dalam dalam pengeluaran glukosa hepatic, stimulasi ambilan glukosa di otot skelet dan sekresi insulin dari sel B pankreas (11). Hati yang terpapar FFA dalam konsentrasi tinggi akibat kompensasi hiperinsulinemia yang menghambat lipolisis sel lemak intra abdomen. Fenomena ini menstimulasi glukoneogenesis, serta sintesis dan sekresi VLDL. Tingginya aktifitas enzim hepatic lipase ( $\mathrm{HL})$, merupakan faktor yang berkontribusi penurunan 
kolesterol HDL. Peningkatan konsentrasi trigliserida disebabkan oleh meningkatnya produksi VLDL dan katabolisme VLDL yang lambat (39).

Salah satu dari intermediet asam lemak yang dapat menginduksi resistensi insulin adalah diasilgliserol. Diasilgliserol dapat mengaktifkan isofom yang berbeda dari protein kinase $C$ (PKC) dan mengaktifkan PKC yang secara langsung menghambat signaling insulin melalui posporilasi dari IRS insulin receptor substrate-1), akibatnya reseptor insulin tidak aktif (39). Axen et al, melaporkan bahwa pemberian diet tinggi lemak pada tikus Sprague Dawley tidak menyebabkan perbedaan kadar gula darah puasa yang signifikan dibanding diet standar (40). Penelitian lain Buettner et al, dengan pemberian diet tinggi lemak signifikan terjadi peningkatan kadar glukosa darah. Pemberian diet tinggi lemak akan mengakibatkan peningkatan kadar gula darah puasa yang disebabkan terjadinya resistensi terhadap aksi insulin (41). Sebagaimana dalam penelitian ini bahwa dengan diet tinggi lemak dapat meningkatkan kadar glukosa darah yaitu terdapat perbedaan bermakna antara yang diberi diet tinggi lemak dengan kontrol. Peningkatan kadar glukosa darah pada keadaan normal akan merangsang sel beta untuk mensekresikan insulin yang akan menyebabkan masuknya glukosa ke dalam sel untuk digunakan sebagai energi, menghambat lipolisis, dan menekan produksi glukosa oleh hati. Dengan terjadinya resistensi insulin, sel tidak mampu merespon peningkatan kadar gula darah sehingga kadarnya akan tetap meninggi.

Dengan pemberian EGCG pada penelitian ini kadar glukosa darah dapat diturunkan walaupun tidak sama dengan kelompok kontrol. Sebagaimana telah diteliti pada penelitian sebelumnya bahwa ekstrak teh hijau maupun katekin akan menurunkan atau mencegah kenaikan kadar gula darah puasa pada tikus jenis Wistar dan Sprague Dawley yang diberi diet tinggi lemak $(22,42,43)$. Salah satu alasannya karena katekin bersifat insulinomimetik. Law et al melaporkan bahwa EGCG pada teh hijau meningkatkan fosforilasi tirosin dari reseptor insulin dan IRS-1 dan mengurangi ekspresi gen PEP karboksilase. EGCG juga menyerupai insulin dengan meningkatkan fosfoinositida 3 kinase, mitogen-activated protein kinase dan aktivitas p70. Selain itu, efek ini juga

\section{DAFTAR PUSTAKA}

1. Pimentel GD. AMP-Activated Protein Kinasen (AMPK)the Key Role in Metabolic and Control of Food Intake. Nutrire Revista da Sociedade Brasileira de Alimentação e Nutrição Journal of The Brazillian Society of Food and Nutrition. 2009; 34: 159-173.

2. Departemen Kesehatan RI. Laporan Hasil RISKESDAS Nasional. Jakarta: Departemen Kesehatan RI. 2008.

3. Cook A and Cowan C. Adipose the Stem Cell Research Community. Boston: Harvard Stem Cell Institute; 2009.

4. Kopelman PG, Caterson IP, and Dietz WH. Clincal Obesity in Adulth and Children. 3rd edition. State Avenue, Ames: Wiley Blackwell; 2010.

5. Ferre P and Foufelle F. Transcription Factor and Lipid Homeostasis: Clinical Perspective. Hormone Research. 2007: 68; 72-82. dijelaskan melalui regulasi gen yang mengkode enzimenzim glukoneogenik dan fosforilasi tirosin. Resistensi insulin akan menyebabkan tidak dapat masuknya glukosa ke dalam sel dan meningkatnya produksi glukosa hepatic yang akan memperparah keadaan hiperglikemia. Peningkatan kadar glukosa darah puasa menunjukkan adanya gangguan dalam toleransi glukosa yang mengambarkan resistensi akan aksi insulin (32).

EGCG dengan komponen utamanya katekin pada teh hijau, merupakan kompunen bioaktif penting dalam pengaturan glukosa, pada kultur adiposit ekstrak teh hijau bekerja seperti insulin. Penelitian pada hewan coba EGCG meningkatkan toleransi glukosa dan sensitifitas insulin $(20,44)$, EGCG juga menghambat aktifasi I-kappa kinase , serin/treonin kinase yang berperan dalam pathogenesis resistensi insulin (45). Tidak ada perbedaan kadar insulin antara kontrol negatif dan kontrol positif demikian juga pada kelompok dengan pemberian EGCG. Seperti yang dijelaskan pada kerangka konsep bahwa peningkatan insulin yang mempengaruhi peningkatan kadar SREBP-1 sehingga terjadi hipertropi dan hiperplasia jaringan adiposa dan pemicu terjadinya resistensi insulin. Dengan kata lain bahwa ekspresi SREBP-1 pada penelitian ini tidak ada hubungannnya dengan insulin.

Sebuah penelitian yang dilakukan oleh Deniau et al menyimpulkan bahwa glukosa tanpa adanya insulin, mengatur ekspresi SREBP-1c pada otot skeletal (46). Glukosa menginduksi SREBP-1c dengan menghambat phosphatidylinositol-3-kinase, menghambat mitogenactivated-protein-kinase (MAPK) pathway. Glukosa mengatur ekspresi SREBP-1c di sel otot skeletal melalui Interaksi antara Jak2 dan reactive oxygen species (ROS), karena ROS menstimulasi aktifitas Jak2, glukosa tinggi melalui jalur polyol menginduksi peningkatan ROS melalui aktifasi PKC mempengaruhi sinyal transduksi melalui protein-tyrosine phosphatases oleh aktifitas Jak2 $(47,48)$. Peningkatan ekspresi SREBP-1c oleh glukosa berhubungan dengan enzim lipogenik dan penumpukan lemak intaseluler baik di intra muscular maupun di sel sel $\beta$-pancreas. Kelebihan simpanan lemak di jaringan nonadiposa berkontribusi pada terjadinya lipotoksisitas dan pemicu resistensi insulin (12).

6. Shimano H. SREBPs: Physiology and Pathophysiology of the SREBP Family. FEBS Journal. 2008: 276(3); 616-621.

7. Kim JB, Sarraf P, Wright M, et al. Nutritional and Insulin Regulation of Fatty Acid Synthetase and Leptin Gene Ekspresi Throught ADD1/SREBP-1. Journal of Clinical Investigation. 1998: 101(1); 1-9.

8. Horton JD, Goldstein JL, and Brown MS. Activators of Complete Program of Cholesterol and Fatty Acid Synthesis in the Liver. Journal of Clinical Investigation. 2002: 109: 1125-1131

9. Desvergne B, Michalik L, and Wahli W. Transcriptional Regulation of Metabolism. Physiological Review. 2006: 86; 465-514.

10. Coleman RA, Lewin TM, and Muoio D. Physiological and Nutritional regulation of enzymes of triacylgycerol Synthesis. Annual Review of Nutrition. 2000: 20; 77- 
103

11. Kahn BB and Flier JS. Obesity and Insulin resistence. Journal of Clinical Investigation. 2000: 106(4); 473481.

12. Unger RH and Orci L. Diseases of Liporegulation: New Perspective On Obesity and Related Disorders. FEBS Journal. 2001: 15(2); 312-321.

13. Dominic S. Insulin Resistance, Diabetes and its Complications. In: Robert A. Meyers (Ed). Encyclopedia of Molecular Cell Biology and Molecular Medicine 2nd edition. Wenheim: Willey-VCH; 2005.

14. Park S, Kim YW, Kim JY, Jang K, and Lee SK. Effect of High Fat Diet on Insulin Resitance: Dietary Fat Versus Visceral Fat Mass. Journal of Korean Medical Science. 2001: 10; 580-590.

15. Blaak. Fatty Acids: Friends or Foe? Relation Betwen Dietary Fat and Insulin Sensitivity. Immunology, Endocrine \& Metabolic Agents - Medicinal Chemistry. 2007: 7; 31-37.

16. Intan $M$ and Wijaya A. Obesitas dan Sindroma Metabolik. Laboratorium Klinik Prodia. Forum Diagnosticum. 2004: 5.

17. Fashauer $M$ and Pasche R. Regulation of Adipocytokines and Insulin Resistance. Diabetologia. 2003: 46 (12); 1594-1603.

18. Chen N, Bezzina R, Hinch E, et al. Green Tea, Black Tea, and Epigallocatechin Modify Body Composition, Improve Glucose Tolerance, and Differentially Alter Metabolic Gene Expression in Rats Fed a High-Fat Diet. Nutrition Research. 2009: 29; 784-793

19. Lee MS, Kim CT, and Kim Y. Green Tea (-)Epigallocatechin-3-Gallate Reduces Body Weight with Regulation of Multiple Genes Expression in Adipose Tissue of Diet-Induced Obese Mice. Annals of Nutrition and Metabolism. 2009: 54(2);151-157.

20. Wolfram S, Raederstorff D, Wang Y, Teixeira, SR, Elste, V, and Weber P. TEAVIGO (Epigallocatechin Gallate) Supplementation Prevent Obesity in Rodent by Reducing Adipose Tissue Mass. Annals of Nutrition and Metabolism. 2005: 49(1): 54-63.

21. Klaus S, Pultz S, Thone RC, and Wolfram S. Epigallocathechin Gallate Attenuates Diet-Induced Obesity in Mice by Decreasing Energy Absorption and Increasing Fat Oxidation. International Journal of Obesity. 2005: 29(6); 615-623.

22. Anderson RA and Polansky MM. Tea Enhances Insulin Activity. Journal of Agricultural and Food Chemistry. 2002: 50(24); 7182-7186.

23. Sohle J, Knott A, Holtzmann U, et al. White Tea Extract Induces Lipolytic Activity and Inhibits Adipogenesis in Human Subcutaneous (Pre)-Adipocytes. Nutrition \& Metabolism. 2009: 6: 20

24. Bose M, Lambert JD, Ju J, Reuhi KR, Shapses SA, and Yang CS. The Major Green Tea Polyphenol, (-)Epigallocatechin-3-gallate, Inhibit Obesity, Metabolic Syndrome, and Fatty liver Disease in High-fat-fed Mice. Journal of Nutrition. 2008: 138(9); 1677-1683.

25. Ratnawati R, Ciptati, dan Satuman. Isolasi EGCG dari Teh Hijau Klon GMB4 Jawa Barat. [Laporan Penelitian
Program Insentif Riset Dasar RISTEK Kementerian Negara Riset dan Teknologi]. Universitas Brawijaya Malang. 2009.

26. Wilde JD, Smit E, Mohren R, et al. An 8-Week High-Fat Diet Induces Obesity and Insulin Resistance with Small Changes in the Muscle Transcriptome of C57BL/6J Mice. Journal of Nutrigenetic and Nutrigenomics. 2009:2(6); 280-291.

27. Vessby B, Uusitupa M, Hermansen K, et al. Substituting Dietary Saturated for Monounsaturated Fat Impairs Insulin Sensivity in Healthy Men and Women; The KANWU Study. Diabetologia. 2001:44;312-319

28. Griffin ME, Marcucci MJ, Cline GW, et al. Free Fatty Acid-Induced Insulin Resistance is Associated with Activation of Protein Kinase C Theta and Alterations in the Insulinsignaling Scade. Diabetes. 1999: 48(6); 1270-1274.

29. Simpson ER, Clyne C, Rubin G, et al. Aromatase: a Brief Overview. Annual Review Physiology. 2002: 64; 93127

30. Heine PA, Taylor JA, Iwamoto GA, Lubahn DB, and Cooke PS. Increased Adipose Tissue in Male and Female Estrogen Receptor-Alpha Knockout Mice. Annual Meetings of the Society for the Study of Reproduction. Pullman, July 31-August 3, 1999, and Madison, July 15-18, 2000.

31. Koyama Y, Abe K, Sano Y, et al. Effects Of Green Tea on Gene Expression of Hepatic Gluconeogenic Enzymes in Vivo. Planta Medica. 2004: 70(11); 1100-1102.

32. Waltner-Law ME, Wang XL, Law BK, Hall RK, Nawano $\mathrm{M}$, and Granner DK. Epigallocatechin Gallate, a Constituent of Green Tea, Represses Hepatic Glucose Production. The Journal of Biological Chemistry. 2007: 282(41); 30143-30149.

33. Chien PJ, Chen YC, Lu SC, and Sheu F. Dietary Flafonoids Suppress Adipogenesis in 3T3-LI Preadipocytes. Journal of Food and Drug Analysis. 2005: 13(2); 168175

34. Lin J, Mary ADF, and Clifton AB. Green Tea Polyphenol Epigallocatechin Gallate Inhibits Adipogenesis and Induces Apoptosis in 3T3-L1 Adipocytes. Obesity Research. 2005: 13(6); 982-990.

35. Shrestha S, Ehlers SJ, Lee JY, Fernandez ML, and Koo SL. Dietary Green Tea Extract Lowers Plasma and Hepatic Triglycerides and Decreases the Expression of Sterol Regulatory Element Binding Protein-1c mRNA and its Responsive Genes in Frutose Fed, Ovariectomized Rats. Journal of Nutrition. 2009: 139(4); 640-645.

36. Bray GA. Medical Consequences of Obesity. The Journal of Clinical Endocrinology and Metabolism. 2004: 89(6); 2583-2589.

37. Meier $U$ and Gressner AM. Endokrine Regulation of Energy Metabolism: Review of Pathobiochemical and Clinical Chemical Aspects of Leptin, Ghrelin, Adiponectin, and Resistin. Clinical Chemistry. 2004: 50(9); 1511-1525.

38. Despres J and Krauss RM. Obesity and Lipoprotein Metabolism. In: Bray GA (Ed). Handbook of Obesity. New York: Marcel Dekker Inc.; 1998: p. 651-676. 
39. Chen HC, Sajan MP, Standaert ML, et al. Role of Adypocyte Derivate Factor Enhancer Insulin Signaling in Skeletal, White Adypocyte Tissue in Mice Lack in Acyl-Coa Diacylglycerol Transferase. Diabetes. 2004: $53 ; 1445-1451$

40. Axen KV and Axen K. Very Low-Carbohydrate Versus Isocaloric Highcarbohydrate Diet in Dietary Obese Rats. Obesity. 2006: 14(8); 1344-1352

41. Buettner R, Parhofer KG, Woenckhaus $M$, et al. Defining High-Fat-Diet Rat Models: Metabolic and Molecular. Journal of Molecular Endocrinology. 2006: 36(3); 485-501.

42. Wu LY, Juan CC, Ho LT, Hsu YP, and Hwang LS. Effect of Green Tea Supplementation on Insulin Sensitivity in Sprague-Dawley Rats. Journal of Agricultural Food Chemistry. 2004: 52(3); 643-648.

43. Ashida H, Furuyashiki T, Nagayasu H, et al. AntiObesity Actions of Green Tea: Possible Involvements in Modulation of the Glucose Uptake System and Suppression of the Adipogenesis-Related Transcription Factors. BioFactors. 2004: 22(1-4); 135140.

44. Potenza MA, Marasciulo FL, Tarquinio $M$, et al. EGCG, a Green Tea Polyphenol, Improves Endothelial
Function and Insulin Sensitivity, Reduces Blood Pressure, and Protects Against Myocardial I/R Injury in $S H R$. American Journal of Psyhiology-Endocrinology and Metabolism. 2007: 292(5); 1378-1387.

45. Chen PC, Wheeler DS, Malhotra V, Odoms K, Denenberg AG, and Wong HR. A Green Tea-Derived Polyphenol, Epigallocatechin-3-Gallate, Inhibits I Kappa B Kinase Activation and IL-8 Gene Expression in Respiratory Epithelium. Inflammation. 2002: 26(5); 233-241.

46. Deniau IG, Pichard AL, Koné A, et al. Glucose Induces De Novo Lipogenesis in Rat Muscle Satellite Cells Through a Sterol-Regulatory-Elementbinding-Protein1c-Dependent Pathway. Journal of Cell Science. 2004: 117 (10); 1937-1944.

47. Nishikawa T, Edelstein D, Du XL, et al. Normalizing Mitochondrial Superoxide Production Blocks Three Pathways of Hyperglycaemic Damage. Nature. 2000: $404 ; 787-790$.

48. Shaw S, Wang X, Redd H, Alexander GD, Isales CM, and Marrero MB. High Glucose Augments the Angiotensin II-Induced Activation of JAK2 in Vascular Smooth Muscle Cells Via the Polyol Pathway. The Journal of Biological Chemistry. 2003: 278(33); 30634-30641. 